\title{
VYUŽITÍ GAMASPEKTROMETRIE PŘI STUDIU SPODNOBADENSKÝCH SEDIMENTU゚ VE VRTU 2241_B BRNO-ČERNÁ POLE
}

\author{
Use of gamma-ray spectrometry for the study of Lower Badenian deposits in the borehole \\ 2241_B Brno-Černá Pole
}

\author{
Lucie Dostalíková, Hana Valentíková, Slavomír Nehyba \\ Ústav geologických věd, Prírodovědecká fakulta, Masarykova univerzita, Kotlářská 2, 61137 Brno; \\ e-mail:411593@mail.muni.cz; 409133@mail.muni.cz; slavek@sci.muni.cz
}

(24-32 Brno)

Key words: Carpathian Foredeep, Lower Badenian, Neogene deposits, gamma ray logging, clastic sediments

\begin{abstract}
Lower Badenian deposits represent volumetrically significant part of the Carpathian Foredeep infill. New drilled borehole 2241_B Brno-Černá Pole recorded sedimentary profile of these deposits with an almost complete core data. Two different Lower Badenian facies were documented. The first facies of calcareous clays (Tegel) have been documented in depths 20-167 m. Calcareous clays cover underlying "Brno sands", which represent the second lithofacies and were recorded in depths 167-236 m. Gamma-ray spectrometry was studied on 418 samples of both clays and sands. The results show significant differences in both concentrations and source of signal for these two lithofacies. Lower Badenian clays reveal in general relatively higher concentrations of Th and K than was recognised for Lower Badenian sands. However, concentrations of U are higher in Lower Badenian sands. Remarkable is unusually high U content in selected samples from "Brno sands" (which was also confirmed by supplementary XRF analyses). Whereas Lower Badenian clays were deposited in mostly oxidic condition, deposition of "Brno sands" reveals more reducing conditions. The value $T h / K$ points to varying mineralogy of clays, which is preliminary connected with alternation of more or less humid/arid climatic phases during Lower Badenian. Similar differences within the Lower Badenian sands are explained by source area variations.
\end{abstract}

Úvod

Spodnobadenské sedimenty představují v Brně a jeho nejbližším okolí nejrozsáhlejší a nejmocnější z miocenních sedimentů karpatské předhlubně (Krystek 1982).

V roce 2015 byl v rámci projektu České geologické služby s názvem „Rebilance zásob podzemních vod“ odvrtán vrt (N $49^{\circ} 12^{\prime} 56^{\prime \prime}$, E $\left.16^{\circ} 36^{`} 45^{\prime \prime}\right)$ s označením 2241_B Brno-Černá Pole. Pozice vrtu je znázorněna na obrázku 1. Vrt dosáhl hloubky $361 \mathrm{~m}$, príčemž v metráži $20-236 \mathrm{~m}$ protnul spodnobadenské sedimenty karpatské předhlubně (Tomanová Petrová et al. 2015). Vzhledem k téměř kontinuálnímu vrtnému jádru se tak naskytla ojedinělá možnost detailněji zhodnotit sled těchto sedimentů v zájmové oblasti. Spodnobadenské sedimenty zde vystupují ve dvou naprosto dominantních a výrazně odlišných litofaciích - tj. jako vápnité prachovité jíly (tzv. tégly - metráž 20 až $167 \mathrm{~m}$ ) a štěrkovité písky až písčité štěrky (tzv. brněnské písky - metráž 167-236 m). Detailněǰ̌í vnitřní členění těchto dvou litofacií tradičně naráží na nutnost využití časově náročných paleontologických, petrologických a geochemických technik. Předložený př́spěvek představuje možnost využití gamaspektrometrie, která se jeví jako relativně rychlá a finančně nenáročná metoda ke studiu monotónních sedimentárních sekvencí.

\section{Geologická situace zájmové oblasti}

Vrtem 2241_B Brno-Černá Pole byly zastiženy sedimenty kvartéru, spodnobadenské sedimenty karpatské předhlubně, sedimenty paleogénu nesvačilského prŕíkopu a horniny brněnského masivu.

Karpatská předhlubeň na Moravě je součástí periferních alpsko-karpatských pánví v předpolí flyšových jednotek. Dnes zabírá větší části moravských úvalů, Vyškovské a Moravské brány, Ostravsko, Opavsko a pokračuje

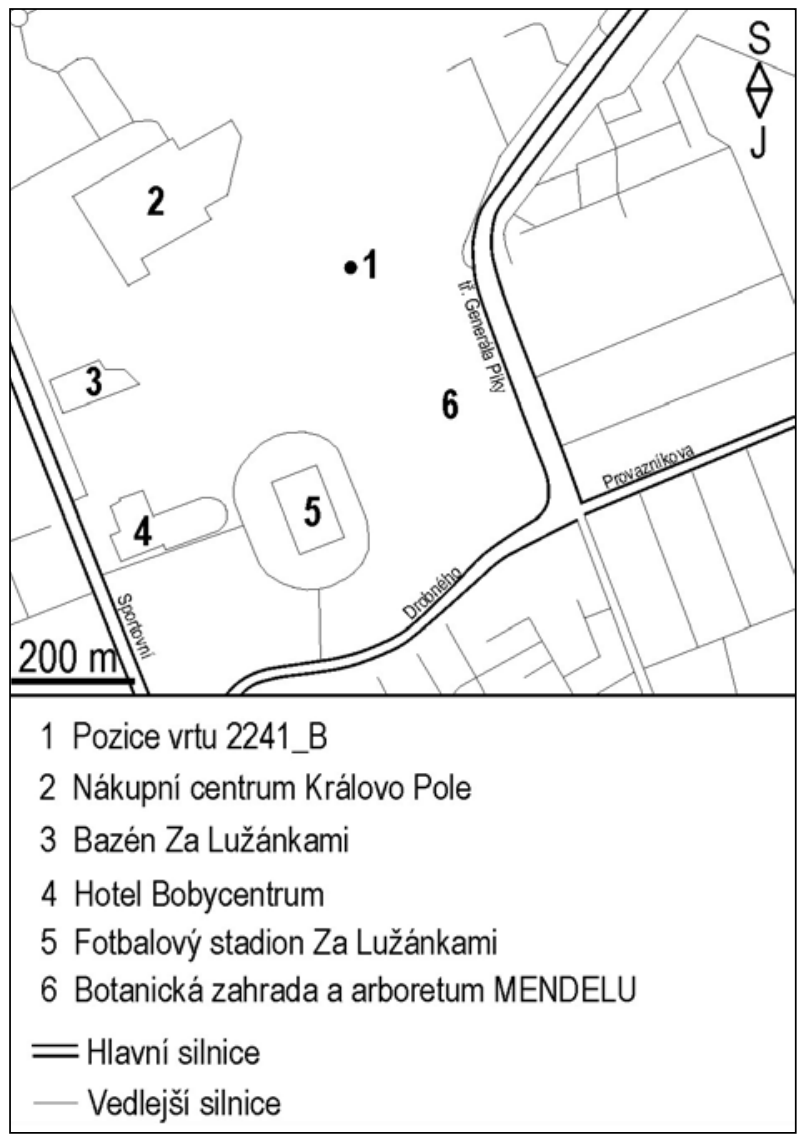

Obr. 1: Pozice vrtu.

Fig. 1: Position of borehole. 
na J do molasové zóny Rakouska a na $\mathrm{S}$ do karpatské předhlubně Polska (Brzobohatý - Cicha 1993).

Spodnobadenské sedimenty karpatské předhlubně na Moravě reprezentují převážně závěrečný úsek marinní depozice této periferní předpolní pánve Východních Alp a západních Karpat (Doláková et al. 2008).

$\mathrm{Na}$ bázi vrstevního sledu spodnobadenských sedimentů byly zjištěny velmi hrubozrnné písky se štěrkem, které jsou interpretovány jako „bazální“ klastika spodnobadenského stáří, označovaná v zájmové oblasti obecně jako brněnské písky (Krystek 1974; Nehyba et al. 2008). Tyto brněnské písky jsou rozšířeny především na horninách brněnského masivu. Obzvláště velké mocnosti ( $175 \mathrm{~m})$ dosahují brněnské písky v oblasti sz. okraje nesvačilského př́kopu (Krystek 1974). Jsou to žlutošedé, hnědošedé až hnědožluté, středně až hrubě zrnité, místy štěrkovité, silně vápnité písky a hnědošedé, šedé až šedohnědé, proměnlivé písčité vápnité štěrky. Často jsou rezavě zbarveny hydroxidy železa. Pro štěrky je typická ukloněná laminace a šikmé zvrstvení velké škály. Zdrojem jejich valounového materiálu byly především horniny brněnského masivu spolu se sedimenty stáŕí jura a paleozoikum. Štěrky a písky spodního badenu jsou zrnitostně většinou velmi špatně vytříděné (Müller et al. 2000). Novější studia o brněnských píscích publikoval Nehyba et al. (2008).

Litologicky převažujícími horninami spodního badenu jsou vápnité jíly, v karpatské předhlubni označované jako „tégly“ (Müller et al. 2000). Nasedají ostře na starší spodnobadenská klastika nebo přímo na starší předneogenní podklad (Brzobohatý - Cicha 1993). Pelity jsou nejčastěji modravě šedé, světle šedé až šedé, místy nazelenalé až nahnědlé, proměnlivě jemně písčité až prachovité silně vápnité. Ve výchozech získávají v důsledku navětrání rezavě hnědé zabarvení a nepravidelně kusovitě se rozpadají. Většinou jsou nevrstevnaté nebo jen velmi špatně vrstevnaté. Spodnobadenské jíly obsahují bohatou mikrofaunu, $v$ níž často převládá plankton nad bentosem (Müller et al. 2000). Jde zejména o schránky foraminifer, radiolarií, ostrakodů a o otolity kostnatých ryb. Vzácně jsou $\mathrm{v}$ jílech přítomny také zbytky makrofauny, hlavně měkkýšů, korálů, fragmenty a ostny ježovek a zbytky živočišných hub.

\section{Metodika}

Měření přirozené radioaktivity proběhlo na gamaspektrometru GR-320 enviSPEC s relativní odchylkou měření Th 0,5 ppm, U 0,3 ppm a K 0,2\%, který je umístěn na ÚGV PřF MU v Brně. Vzorky pro gamaspektrometrickou analýzu byly uzavřeny v plastovém pouzdru a zváženy na digitální váze. Váha měřených vzorků se pohybovala v rozmezí 131,26-414,33 g. Každé měření přirozených radionuklidů a celkové radioaktivity sedimentu bylo po kalibraci prováděno po dobu 30 minut. Výsledky byly zobrazeny $\mathrm{v}$ počítačovém programu LAB Center, který vyhodnocuje obsahy radionuklidů $\mathrm{K}, \mathrm{U}$ a Th. Vzorky $s$ „nápadně“ vysokými hodnotami některých radionuklidů byly měřeny opakovaně (tj. $4 \times$ ), aby byla eliminována možná chyba měření.
Přírodní záření gamma je $\mathrm{v}$ horninách naprosto dominantně odrazem koncentrací tří prvků a produktů jejich rozpadu, tj. ${ }^{40} \mathrm{~K}$, izotopů Th a U. Gamaspektrometrie umožňuje odlišit zastoupení těchto jednotlivých radionuklidů. Řada autorů potvrzuje, že výsledky gamaspektrometrie lze využít pro určení litologie, zrnitosti, vytř́ídění, procesů a složení zdrojové oblasti, identifikaci jílových minerálů, obsahu organického uhlíku, odlišení depozičního prostředí, celopánevní korelace atd. (Rider 1996; Ruffell - Worden 2000; Akinlotan 2017). Celková radioaktivita byla vypočtena jako tzv. standardní gamazáření (SGR) dle vzorce SGR [API] = 16,32 × K (\%) + 8,09 $\times \mathrm{U}(\mathrm{ppm})+3,93 \times \mathrm{Th}(\mathrm{ppm})-\mathrm{API} /$ American Petroleum Institute units.

\section{Výsledky}

$\mathrm{V}$ rámci vrstevního sledu pelitů bylo měřeno 293 vzorků. Vzorky byly odebírány s víceméně pravidelným krokem $50 \mathrm{~cm}$.

Koncentrace draslíku se ve spodnobadenských pelitech pohybují v rozmezí $0,97-2,91 \%$, průměrná hodnota je 2,08\% (směrodatná odchylka 0,28). Zastoupení uranu se pohybuje v rozmezí 1,06-6,63 ppm s průměrnou hodnotou 2,19 ppm (směrodatná odchylka 0,57 ). Koncentrace thoria se pohybují v rozmezí 5,63-12,86 ppm s průměrnou hodnotou 8,73 ppm (směrodatná odchylka 1,1). Dle hodnocení Hesselbo (1996) se koncentrace draslíku a uranu pohybují od nízkých po vysoké, koncentrace Th lze pak považovat za střední a vysoké. Podíváme-li se detailněji na distribuci jednotlivých prvků (viz obr. 2), tak vzorky $s$ vysokými koncentracemi $\mathrm{K}$ převažují nad vzorky se středními hodnotami koncentrací. Vzorky s nízkými koncentracemi K jsou ojedinělé. V př́ípadě uranu naopak naprosto dominují vzorky s nízkými koncentracemi. Vzorky s vyššími a středními hodnotami přítomnosti uranu jsou ojedinělé. Vzorky s vysokými hodnotami thoria zcela převažují, střední hodnoty jsou ojedinělé. Koncentrace Th vykazují téměř symetrickou distribuci ve studovaných vzorcích. Celková radioaktivita SGR se pohybuje od 52,5 po 127,8 API. Průměrná hodnota SGR je 85,9 API a směrodatná odchylka 7,95.

Hodnoty poměru $\mathrm{Th} / \mathrm{K}$ se pohybují v rozmezí 2,65-6,81 s průměrnou hodnotou 4,24 (směrodatná odchylka 0,6), jsou tedy relativně nízké (dle Hesselbo 1996). Hodnoty poměru Th/U nabývají hodnot 1,01-11,12 s průměrem 4,24 (směrodatná odchylka 1,25 ), což ukazuje, že se tyto poměry pohybují od nízkých po vysoké. Celkové koncentrace Th vs. K vykazují středně silnou pozitivní korelaci $(\mathrm{r}=0,446)$. Koncentrace K vs. U vykazují velmi slabě zápornou korelaci $(\mathrm{r}=-0,080)$ a koncentrace Th vs. U slabě zápornou korelaci $(r=-0,274)$. Hodnota celkové radioaktivity SGR vykazuje pozitivní korelaci se všemi sledovanými radionuklidy, přičemž nejvyšší je k zastoupením draslíku $(r=0,64)$ a thoria $(r=0,64)$ a nižší s koncentracemi uranu $(\mathrm{r}=0,39)$.

$\mathrm{V}$ případě brněnských písků byly hodnoty koncentrace $\mathrm{K}, \mathrm{U}$ a Th měřeny u 125 vzorků odebraných $\mathrm{z}$ vrtných jader s víceméně pravidelným krokem $50 \mathrm{~cm}$. „Klastika“ vykazují relativně nižší rozptyl hodnoty koncentrací 


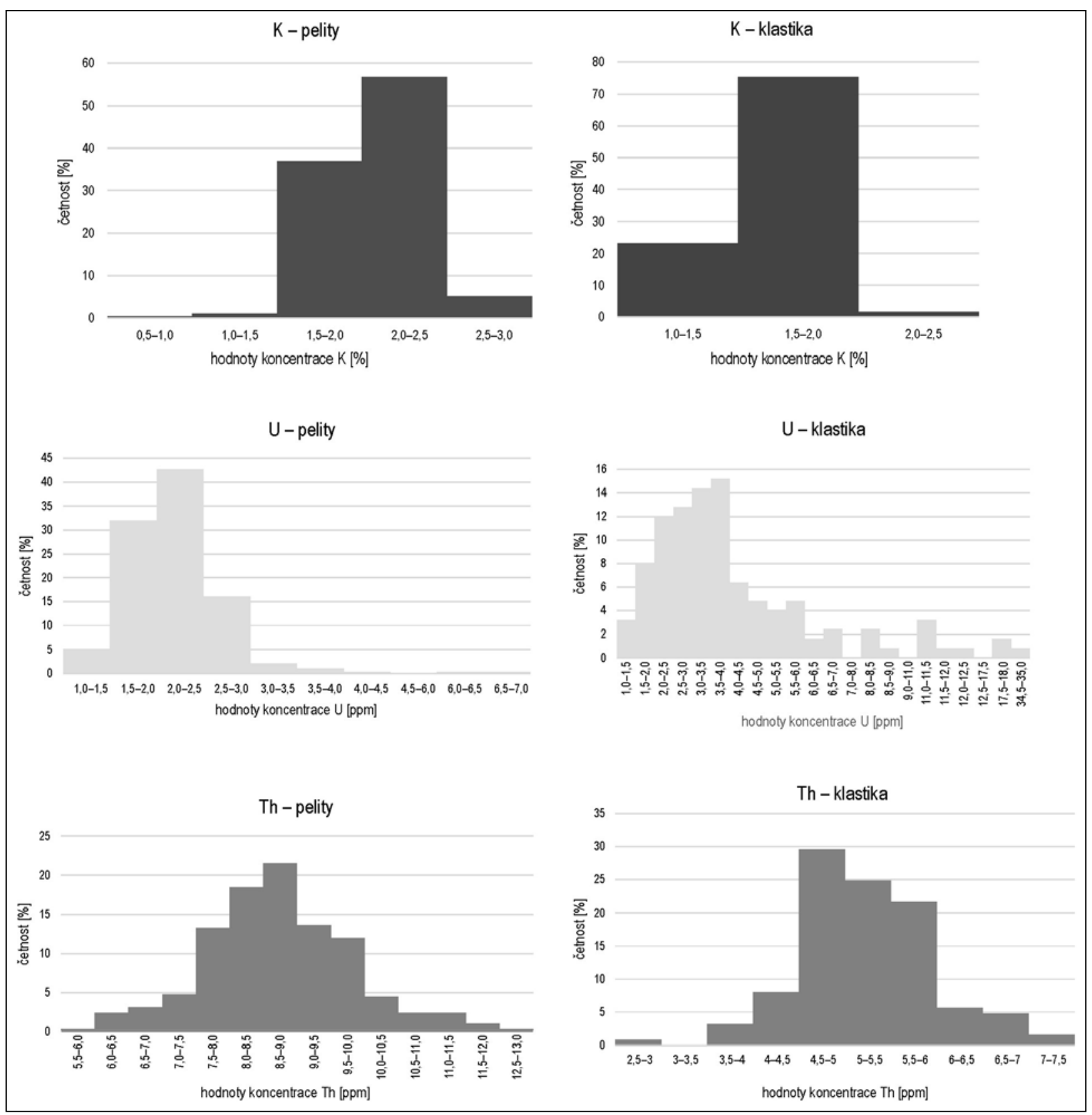

Obr. 2: Histogramy hodnot K, U a Th pelitů a "klastik“.

Fig. 2: Histograms of values $K, U$ and Th of pelites and „clastics“.

K, tj. 1,30-2,06\%. Průměrná hodnota koncentrace K činí $1,61 \%$ (směrodatná odchylka 0,14 ). Koncentrace U byly značně proměnlivé, nejnižší hodnota dosahovala 1,26 ppm, zatímco koncentrace uranu vzorku odebraného v 224,25 m dosahuje velmi vysoké hodnoty, tj. 34,98 ppm. Průměrná hodnota je tedy vcelku vysoká, tj. 4,47 ppm (směrodatná odchylka 3,94). Hodnoty koncentrace Th nejeví žádné výraznější výkyvy a pohybují se od 2,58 do 7,10 ppm. Průměrná hodnota koncentrací Th činí 5,21 ppm (směrodatná odchylka 0,74 ). Dle hodnocení Hesselbo (1996) se koncentrace draslíku pohybují od středních po vysoké, koncentrace uranu i thoria od nízkých po vysoké. Podíváme-li se detailněji na distribuci jednotlivých prvků (viz obr. 2), tak vzorky se středními koncentracemi $\mathrm{K}$ naprosto převažují nad vzorky $\mathrm{s}$ vysokými hodnotami, které jsou ojedinělé. $\mathrm{V}$ př́ípadě uranu převažují vzorky s jeho nízkými koncentracemi. Vzorky s vyššími a středními hodnotami přítomnosti uranu jsou ovšem také relativně významně zastoupeny. Je zřejmé, že distribuce uranu ve sledovaných vzorcích nevykazuje pravidelné rozdělení. Vzorky se středními hodnotami thoria naprosto převažují, vzorky s nízkými hodnotami jsou ojedinělé a vzorky s vysokými hodnotami výrazně méně časté. Koncentrace Th vykazují relativně symetrickou distribuci ve studovaných vzorcích. Celková radioaktivita SGR se pohybuje ve velmi širokém rozmezí od 47,7 po 325,2 API. Průměrná hodnota SGR je 83,0 API a směrodatná odchylka 31,73 .

Hodnoty poměru Th/K se pohybují v rozmezí $1,82-4,59$, když průměrná hodnota poměru $\mathrm{Th} / \mathrm{K}$ je 3,25 (směrodatná odchylka 0,52 ). Tyto hodnoty jsou tedy relativně nízké (Hesselbo 1996). Hodnoty poměru 
Tab. 1: Výsledky měření.

Tab. 1: Measurement results.

\begin{tabular}{|c|c|c|c|c|c|c|c|c|c|c|c|c|c|c|c|}
\hline & \multicolumn{3}{|c|}{ DRASLÍK [\%] } & \multicolumn{3}{|c|}{ URAN [ppm] } & \multicolumn{3}{|c|}{ THORIUM [ppm] } & \multicolumn{3}{|c|}{$\mathrm{Th} / \mathrm{U}$} & \multicolumn{3}{|c|}{ Th/K } \\
\hline & AVG & MIN. & MAX. & AVG & MIN. & MAX. & AVG & MIN. & MAX. & AVG & MIN. & MAX. & AVG & MIN. & MAX. \\
\hline Pelity & 2,08 & 0,97 & 2,91 & 2,19 & 1,06 & 6,63 & 8,73 & 5,63 & 12,86 & 4,24 & 1,01 & 11,12 & 4,24 & 2,65 & 6,81 \\
\hline Klastika & 1,61 & 1,30 & 2,06 & 4,47 & 1,26 & 34,98 & 5,21 & 2,58 & 7,10 & 1,60 & 0,14 & 4,34 & 3,25 & 1,82 & 4,59 \\
\hline
\end{tabular}

Th/U nabývají hodnot $0,14-4,34$ s průměrnou hodnotou poměru Th/U 1,60 (směrodatná odchylka 0,77 ). Hodnoty poměru Th/U lze tedy považovat za velmi proměnlivé nízké i vysoké. Korelace K a U vykazuje mírně negativní hodnotu $(r=-0,16)$. Korelace mezi K a Th je nízká $(r=0,11)$ a korelace mezi U a Th je velmi nízká $(\mathrm{r}=0,01)$. Hodnota celkové radioaktivity je ideálně korelovatelná se zastoupením uranu $(0,99)$, naopak slabě negativní korelace byla zjištěna mezi hodnotou SGR a zastoupením $\mathrm{K}(\mathrm{r}=-0,1)$ a jen slabě pozitivní mezi hodnotou SGR a koncentracemi Th $(\mathrm{r}=0,1)$. Výsledky měření jsou shrnuty v tabulce 1 .

\section{Interpretace}

Korelace mezi hodnotou celkové radioaktivity SGR a koncentracemi $\mathrm{K}$, Th a U ukazují, že hlavním nositelem úhrnné přirozené radioaktivity je v př́padě pelitů draslík a thorium, naopak v prrípadě klastik je to uran. Pozitivní korelace Th a K pro pelitické sedimenty a zčásti i brněnské písky ukazuje na společný zdroj jejich gamazáření, kdežto negativní korelace těchto dvou prvků s U ukazuje, že původ gamazáření $U$ je odlišný především v rámci pelitických sedimentů. Srovnání absolutních hodnot zastoupení př́rodních radionuklidů pro sledované litofacie spodnobadenských sedimentů ukazuje, že pelitické sedimenty vykazují jen mírně vyšší hodnoty koncentrace K než studované vzorky brněnských písků. Zastoupení draslíku je také ve všech studovaných vzorcích relativně nejméně variabilní. Mírně rozdílné koncentrace $\mathrm{K}$ lze $\mathrm{v}$ rámci brněnských písků částečně vysvětlit rozdílným zastoupením slíd (brněnské písky jako celek jsou slídnaté), a také ve spojitosti s rozdílnou zrnitostí. Koncentrace Th jsou výrazně vyšší v rámci spodnobadenských pelitů než v rámci brněnských písků, přičemž jeho koncentrace vykazují v rámci sledovaných vzorků také vyšší variabilitu.

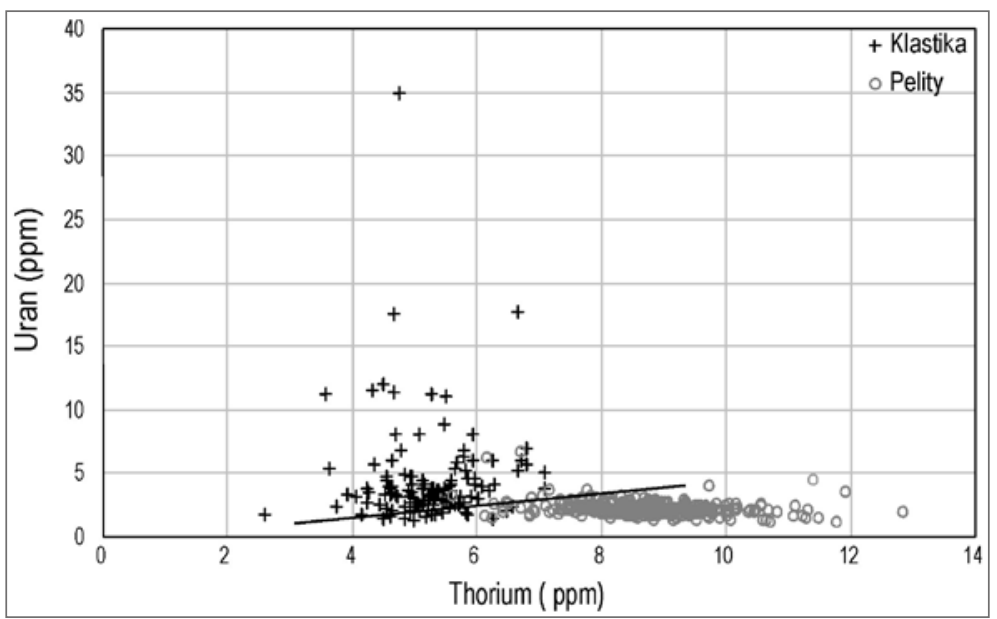

Obr. 3: Graf Th vs. U s diskriminační linií Th/U = 2.

Fig. 3: Crossplot of $U$ versus $T h$ with a discrimination line $T h / U=2$.
Vyšší koncentrace Th a K lze jednoduše vysvětlit zrnitostí, tedy vyšším zastoupením jílových minerálů v pelitech než $\mathrm{v}$ brněnských píscích. Malá proměnlivost $\mathrm{v}$ zastoupení Th a $\mathrm{K} v$ rámci brněnských písků mohou ukazovat na relativně stabilní zdrojovou oblast nebo procesy $v$ jejím rámci. Naopak větší rozdíly v koncentracích těchto prvků v rámci spodnobadenských pelitů ukazují na možnou větší nestabilitu těchto faktorů.

Zdroj gama záření radionuklidů $\mathrm{K}, \mathrm{U}$ a Th lze tedy předběžně hledat $\mathrm{v}$ jednotlivých zrnitostních frakcích. Na rozdíl od pelitů je koncentrace uranu v rámci brněnských písků vyšší (především některé vzorky vykazují velmi vysoké koncentrace $U$ ). Izotopy uranu jsou řazeny mezi nestabilní, proto také koncentrace U ve sledovaných vzorcích celkově projevují nejvyšší variabilitu. Hodnoty celkové radioaktivity SGR jsou velmi proměnlivé zejména $\mathrm{v}$ prrípadě brněnských písků. Průměrná hodnota SGR je sice vyšší pro spodnobadenské pelity, ale absolutně vyšší hodnoty byly zjištěny pro brněnské písky. Tato situace je odlišná od obecných představ, kdy jsou pelitické sedimenty spojovány s vyšší přirozenou radioaktivitou než sedimenty písčité a štěrkovité.

Vzorky spodnobadenských pelitů a „klastik“ se tedy liší v zastoupení a roli jednotlivých sledovaných radionuklidů. Diagram na obrázku 3 (Myers - Wignall 1987) lze využít k odlišení vzorků, v nichž je zastoupení U relativně zvýšené od vzorků, kde je relativně snížené. Je zřetelná odlišná pozice vzorků z pelitů ( $11 \%$ vzorků relativně bohatších $U)$ a vzorků $\mathrm{z}$,klastik“ (63,8 \% vzorků relativně bohatších $\mathrm{U}$ ).

Poměr Th/U je považován za indikátor geochemických facií/oxidačně-redukčních podmínek (Myers - Wignall 1987; Doveton 1991) nebo dokonce depozičního prostředí (Adams - Weaver 1958). Výrazně vyšší hodnoty tohoto poměru zjištěné pro pelitické spodnobadenské sedimenty ukazují na jejich převažující sedimentaci v oxidačních podmínkách. Některé vysoké hodnoty tohoto poměru ukazují na výraznou mobilizaci uranu. Takové podmínky jsou spíše atypické pro prostředí hlubšího moře, kam je sedimentace spodnobadenských pelitů obvykle kladena. Určité zastoupení relativně nižších hodnot tohoto poměru $\mathrm{v}$ rámci pelitů může odrážet měnící se podmínky sedimentace spojené s relativní změnou hladiny. Relativně nízké hodnoty poměru Th/U zjištěné pro brněnské písky ukazují na redukční podmínky depozice a především zvýšenou přítomnost uranu v těchto vzorcích. Zdroj této zvýšené přítomnosti uranu je předběžně hledán $v$ materiálu 


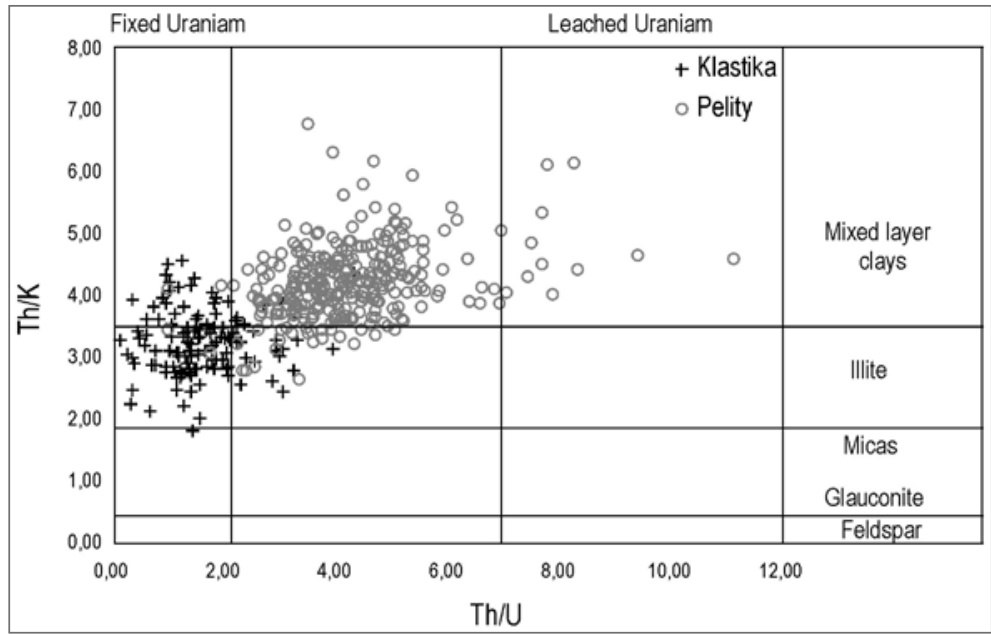

Obr. 4: Graf poměru Th/K vs. Th/U znázorňující dominantní sedimentační prostředí během depozice spodnobadenských sedimentů i druhy jílů.

Fig. 4: Crossplot of $T h / K$ versus $T h / U$ ratios showing the dominant depositional environment during deposition of Lower Badenian sediments as well as the types of clays.

transportovaném do pánve - pravděpodobně se jedná o kř́dové sedimenty. Výrazné rozdíly v hodnotě poměru Th/U v rámci brněnských písků signalizují měnící se podmínky depozice a určité rozdíly v provenienci materiálu. Určitou roli na výkyvech $\mathrm{v}$ zastoupení Th a U mohlo sehrát i proměnlivé zastoupení psefitické frakce (brněnské písky), př́ípadně psamitické frakce a karbonátového materiálu (spodnobadenské pelity).

Poměr Th/K bývá v rámci psefitických sedimentů využíván jako indikátor minerálního složení klastů. Nízká hodnota tohoto poměru (sensu Rider 1996) ukazuje na relativně nízkou koncentraci Th $\mathrm{v}$ brněnských píscích, což lze spojit se zdrojovými horninami, př́ípadně depozičními procesy (e. g. Mange - Rajetzky 1995; Morton - Berge 1995; Morton - Hurst 1995).

Poměr Th/K je v rámci pelitických sedimentů využíván $\mathrm{k}$ identifikaci některých jílových minerálů, př́ípadně zastoupení slíd a K-živce (Doveton - Merriam 2004). Relativně nízké až normální hodnoty tohoto poměru (sensu Rider 1996) ukazují na proměnlivou mineralo- gii spodnobadenských jílů. Tato situace může odrážet klimatické výkyvy během spodního badenu, tj. stř́íání relativně humidnějších a aridnějších klimatických fází (viz např. Holcová et al. 2015; Nehyba et al. 2016).

Interpretaci pomerru $\mathrm{Th} / \mathrm{K}$ ve spojitosti s pomerrem $\mathrm{Th} / \mathrm{U}$ lze sledovat na obrázku 4. Hodnoty poměru Th/K jsou vyšší v př́ípadě spodnobadenských pelitů než $\mathrm{v}$ prrípadě spodnobadenských klastik. Vzhledem $\mathrm{k}$ hloubce pohřbení těchto sedimentů nelze očekávat významné postdepoziční změny jílových minerálů. Spodnobadenské pelity vykazují charakter smíšených jílových struktur pravděpodobně s určitou rolí kaolinitu a smektitu (podobně Nehyba - Jašková 2012; Zborník et al. 2013). Jíly se zvýšeným podílem smektitu jsou typické nízkým obsahem K (Berstad - Dypvik 1982). Relativně neuniformní hodnoty poměru Th/K mohou indikovat rozdíly v mineralogii jílů v rámci „téglü“. Pro brněnské písky lze uvažovat o určité roli illitu př́ípadně K-živce v rámci jemnozrnné zrnitostní frakce. Tyto rozdíly lze nejspíše spojit s rozdílnými zvětrávacími procesy ve zdrojové oblasti (Ruffell - Worden 2000; Schnyder et al. 2006).

Zjištěné výsledky studia zastoupení přirozených radionuklidů budou dále srovnány s výsledky zrnitostního studia, petrografie, faciální analýzy, výsledky měření XRF (také tato metoda potvrdila zvýšené koncentrace U ve vybraných vzorcích brněnských písků), analýzy jílových minerálů a srovnány v profilu vrtu.

\section{Poděkování}

Autoři př́spěvku děkují ČGS za poskytnutí studijního materiálu. Vrtná jádra byla získána v rámci projektu "Rebilance zásob podzemních vod“. Díky patři také recenzentům RNDr. Zuzaně Skácelové a Mgr. Janu Vítovi, Dr. za pripominky k textu. 
Literatura

Adams, J. A. S. - Weaver, E. (1958): Thorium to uranium ratios as indicators of sedimentary process: example of concept of geochemical facies. - AAPG Bulletin, 42, 387-430.

Akinlotan, O. (2017): Geochemical analysis for paleoenvironmental interpretations - a case study of the English Wealden (Lower Cretaceous, south-east England). - Geological Quarterly, 61 (1), 227-238.

Berstad, S. - Dypvik, H. (1982): Sedimentological evolution and sedimentological evolution and natural radioactivity of tertiary sediments from the Central North Sea. - Journal of Petroleum Geology, 5 (1), 77-88.

Brzobohatý, R. - Cicha, I. (1993): Karpatská předhlubeň. - In: Přichystal, A. - Obstová, V. - Suk, M. (eds): Geologie Moravy a Slezska. Sborník př́íspěvků k 90. výročí narození prof. dr. K. Zapletala, 123-128. Moravské zemské muzeum a Sekce geologických věd Přf MU. Brno.

Doláková, N. - Brzobohatý, R. - Hladilová, Š. - Nehyba, S. (2008): The red-algal facies of the Lower Badenian limestones of the Carpathian Foredeep in Moravia (Czech Republic). - Geologica Carpathica, 59 (2), 133-146.

Doveton, J. H. (1991): Lithofacies and geochemical facies profiles from nuclear wireline logs: new subsurface templates for sedimentary modelling. - In: Franseen, E. K. - Watney, W. L. - Kendall, C. J. - Ross, W. (eds): Sedimentary modelling-computer simulations and methods for improved parameter definition. - Kansas Geological Society Bulletin, 233, 101-110.

Doveton, J. H. - Merriam, D. F. (2004): Borehole petrophysical chemostratigraphy of Pennsylvanian black shales in the Kansas subsurface. - Chemical Geology, 206, 249-258.

Hesselbo, S. P. (1996): Stratigraphy, Cenozoic of the Atlantic margin, offshore New Jersey. - In: Mountain, G. S. - Miller, K. G. Blum, P. - Poag, C. W. - Twichell, D. C. (eds): Proceedings of the Ocean Drilling Program. - Scientific Results, 150, 411-422.

Holcová, K. - Hrabovký, J. - Nehyba, S. - Hladilová, Š. - Doláková, N. - Demény, A. (2015): The Langhian (Middle Badenian) carbonate production event in the Moravian part of the Carpathian Foredeep (Central Paratethys): a multiproxy record. Facies, Springer, 61, 1.

Krystek, I. (1982): Miocenní sedimenty na území města Brna. - In: Brno a geologie, ČSVTS, 190-193, Brno.

Krystek, I. (1974): Výsledky sedimentologického výzkumu sedimentů spodního badenu v karpatské předhlubni (na Moravě). Folia UJEP, XV, Geologia, 8, 1-32. Brno.

Mange-Rajetzky, M. A. (1995): Subdivision and correlation of monotonous sandstone sequences using high-resolution heavy-mineral analysis, a case study: the Triassic of the Central Graben. - In: Dunay, R. E. - Hailwood, E. A. (eds): Non-biostratigraphical Methods of Dating and Correlation. - Geological Society, London, Special Publications, 89, 23-31.

Morton, A. C. - Berge, C. (1995): Heavy mineral suites in the Statfjord and Nansen Formations of the Brent Field, North Sea: a new tool for reservoir subdivision and correlation. Petroleum Geoscience, 1, 355-364.

Morton, A. C. - Hurst, A. (1995): Correlation of sandstones using heavy minerals: an example from the Statfjord Formation of the Snorre Field, northern North Sea. - In: Dunay, R. E. - Hailwood, E. A. (eds): Non-biostratigraphical Methods of Dating and Correlation. - Geological Society, London, Special Publications, 89, 3-23.

Müller, P. - Novák, Z. - Bubík, M. - Buriánková, K. - Čurda, J. - Eliáš, M. - Gilíková, H. - Gregerová, M. - Grym, V. - Hanák, J. - Hanžl, P. - Havlíček, P. - Hrádek, M. - Kadlec, J. - Krejčí, O. - Květoňová, E. - Melichar, R. - Müller, V. - Müllerová, H. - Novák, M. - Otava, J. - Pálenský, P. - Petrová, P. - Píše, J. - Sedlák, J. - Šmerdová, B. - Valoch, K. - Vít, J. (2000): Geologie Brna a okolí. - Český geologický ústav. Praha.

Myers, K. J. - Wignall, P. B. (1987): Understanding Jurassic organic-rich mudrocks - new concepts using gamma-ray spectrometry and palaeoecology: examples from the Kimmeridge Clay of Dorset and the Jet Rock of Yorkshire. - In: Legget, J. K. - Zuffa, G. G. (eds): Marine clastic sedimentology: London, Graham and Trotman, 172-189.

Nehyba, S. - Holcová, K. - Gedl, P. - Doláková, N. (2016): The Lower Badenian transgressive-regressive cycles - a case study from Oslavany (Carpathian Foredeep, Czech Republic). - Neues Jahrbuch für Geologie und Paläontologie, Stuttgart, 279, 2, 209-238.

Nehyba, S. - Jašková, V. (2012): Výsledky vrtného průzkumu na lokalitě Hluchov (sedimenty spodního badenu karpatské předhlubně). - Geologické výzkumy na Moravě a ve Slezsku, 19, 1-2, 36-41.

Nehyba, S. - Kirchner, K. - Mackovčin, P. - Demek, J. (2008): Sedimentárně-petrografické studium neogenních a pleistocenních sedimentů v oblasti Brno-Švédské šance. - Geologické výzkumy na Moravě a ve Slezsku v roce 2007, 15, 31-35. Brno.

Rider, M. (1996): The Geological Interpretation of Wireline Logs. Whittles, Caithness.

Ruffell, A. - Worden, R. (2000): Palaeoclimate analysis using spectral gamma-ray data from the Aptian (Cre ta ceous) of southern England and southern France. - Palaeogeography, Palaeoclimatology, Palaeoecology, 155, 265-283.

Schnyder, J. - Ruffell, A. - Deconinck, J. F. - Baudin, F. (2006): Conjunctive use of spectral gamma-ray logs and clay mineralogy in defining late Jurassic-early Cretaceous palaeoclimate change (Dorset, U. K.). - Palaeogeography, Palaeoclimatology, Palaeoecology, 229, 303-320.

Tomanová Petrová, P. - Bubík, M. - Buriánek, D. - Gilíková, H. - Otava, J. - Procházka, M. - Starý, J. - Vít, J. (2015): Závěrečná zpráva průzkumného geologického vrtu 2241_B Brno-Černá Pole. - MS, Závěrečná zpráva, 55 s. Archiv ČGS Praha.

Zborník, V. - Nehyba, S. - Jašková, V. (2013): Výsledky vrtného průzkumu na lokalitě Brus (neogenní sedimenty karpatské předhlubně). - Geologické výzkumy na Moravě a ve Slezsku, 20, 63-68. 